\title{
\begin{tabular}{l|l} 
Mibraries & DSpace@MIT
\end{tabular}
}

\author{
MIT Open Access Articles
}

Markets And Molecules: A Pharmaceutical Primer From The South

The MIT Faculty has made this article openly available. Please share how this access benefits you. Your story matters.

Citation: Banerjee, Dwaipayan. “Markets And Molecules: A Pharmaceutical Primer From The South." Medical Anthropology (July 13, 2016).

As Published: http://dx.doi.org/10.1080/01459740.2016.1209499

Publisher: Taylor \& Francis

Persistent URL: http://hdl.handle.net/1721.1/104645

Version: Author's final manuscript: final author's manuscript post peer review, without publisher's formatting or copy editing

Terms of use: Creative Commons Attribution-Noncommercial-Share Alike 


\section{Markets And Molecules: A Pharmaceutical Primer From The South}

\section{Dwaipayan Banerjee}

To cite this article: Dwaipayan Banerjee (2016): Markets And Molecules: A Pharmaceutical Primer From The South, Medical Anthropology, DOI: 10.1080/01459740.2016.1209499

To link to this article: http://dx.doi.org/10.1080/01459740.2016.1209499

Accepted author version posted online: 13 Jul 2016.

Submit your article to this journal $\widetilde{ }$

Џ Article views: 94

Q View related articles $\asymp$

View Crossmark data $\nearrow$ 


\section{MARKETS AND MOLECULES: A PHARMACEUTICAL PRIMER FROM THE SOUTH}

\section{Dwaipayan Banerjee}

The Indian pharmaceutical industry has historically manufactured low-cost drugs for the global poor. Activist mobilizations at the height of the HIV/AIDS epidemic revealed a vast cost gap between global brands and Indian generics, much to the embarrassment of EuroAmerican corporations that were in the habit of pricing drugs for only the wealthy or well insured. As new drug access controversies focus on anticancer therapies, they reveal new flows of international capital, emergent genetic technologies, and increasingly coercive trade regimes. Together these favor multi-national corporate oligopolies, which imperil the legacy of HIV/AIDS activism and the future availability of essential life-saving drugs for the work of global public health. In this essay, I describe how the future of the right to drug access rests uneasily, and potentially calamitously, on a shifting balance of power between global south interests and Euro-American pharmaceutical capital.

Keywords: cancer, India, law, pharmaceuticals, science, technology

Running title: Markets and molecules

Media teaser: Why are cancer drugs so expensive, and why are their prices not regulated? Why are there so few generics for new medical therapies?

DWAIPAYAN BANERJEE is Assistant Professor of Science, Technology and Society at the Massachusetts Institute of Technology, Building E51, Room 163, Cambridge, MA 02139. Email: dwaibanerjee@gmail.com

In December 2013, the CEO of Bayer Pharma, Marijn Dekkers, caused a media storm for his comments at a Financial Times panel in London. In a conversation on building public trust in Big Pharma, Dekkers responded with unexpected candidness to a question about the unaffordability of Bayer's anticancer drug Nexavar in India: "We did not develop this product for the Indian market, let's be honest. I mean, you know, we developed this product for western patients who can afford this product" (Cassedy 2014). Weeks later, Bayer was embroiled in another public relations fiasco over the same drug. Nina Mahmud - the daughter of an Egyptian cancer patient - made a desperate public plea to the corporation when she found that she could no longer afford her father's treatment: "To afford the next bottle of Nexavar we have to sell the family business which may take a few months and 
will only provide 9 months of Nexavar" (Mahmud 2014). The solution Nina proposed was Bayer's permission to import the drug from India, where licensed generic Nexavar cost only US\$ 120 a month, a fraction of its price of \$3600 a month in Egypt. Bayer had failed in its legal efforts to force the drug off the market in India, but had succeeded in proscribing its circulation outside the country. The corporation replied that as an ethical company, it could not (and would not) violate global intellectual property laws.

Nina Mahmud's inability to afford anticancer drugs is an unfortunately familiar story. Currently, about a dozen global pharmaceutical companies dictate which drugs are researched, developed and manufactured, where they are available, and at what price. And as Dekker's comments reveal, these select corporations are allowed to price certain drugs according to the buying power of the richest and best insured elites in the global north. In what follows, I offer an account of Big Pharma's recent success in releasing cancer drug prices from the limits of state regulations and even free market competition. ${ }^{1}$ This account will begin in India, where both Big Pharma and its opponents aim to establish global rules and precedents for drug pricing and intellectual property. Bayer and other large global corporations invest heavily in litigating within the Indian legal system because of the country's historical status as a supplier of low-cost generics to the global south. Indeed, for its role in providing cheap drugs during the HIV/AIDS crisis, the country's drug manufacturers earned the moniker 'Pharmacy of the Global South' from the health nonprofit Doctors Without Borders (MSF). In part, Big Pharma's oligopolic ambition depends upon its success in combatting the threat of competition from Indian generic manufacturing.

Further, if global controversies about drug access focused on HIV/AIDS therapies at the turn of the century, now the spotlight has turned upon anticancer drugs like Nexavar. In her work on cancer in sub-Saharan Africa, Livingston (2012) describes how the primacy of infectious diseases in the imagination of twentieth century public health led to the neglect of non-communicable diseases. In the last decade, global health specialists have begun to reframe cancer as a public health concern, calling for an end to a persistent differentiation between diseases of the poor and the rich (Farmer, et al. 2010). But as cancer enters the imagination and practice of public health, both state and non-state organizations are forced to confront the exorbitant costs of its therapies. Much is at stake then on collective social forms that coalesce around this disease. In other words, as Jain $(2013,140)$ asks, will cancer evoke the memory of the collective, angry mobilizations around HIV/AIDS at the turn of the century, or will it dissipate into the pervasive ether of corporate pink-ribbon campaigns?

While the outrage over the prohibitive pricing of cancer drugs finds its way into the news media almost every day in the United States, I follow Jain in drawing out the absence of a meaningful, collective response to such rising costs. When AZT - a breakthrough HIV/AIDS therapy - was priced at $\$ 10,000$ a year in the 1980s in the US, organized collectives such as ACT-UP and the Treatment Action Group led a global struggle that publically embarrassed Big Pharma into drastic price cuts. In 1997, the Brazilian government signed a law that made antiretroviral therapy free for all registered patients within the country (Biehl 2004). The same year, South Africa's government, led by Nelson Mandela, began the process of defying World Trade Organization trade regulations to import generics from India for US\$295 per person per year (cf. Bond 1999). Yet memories 
of such struggles have been quick to fade. Big Pharma now commands prices for anticancer drugs that are many times higher than what they had dared for HIV/AIDS therapies. For example, Nexavar costs about $\$ 165,000$ per year per person in the US, sixteen times higher than the original price for AZT. Even worse for patients, as my research into anticancer drug pricing in the United States shows, Big Pharma corporations increase the cost of the same anticancer drugs every year after the drug is introduced into the market. Figure 1 shows this phenomenon in a class of highly effective drugs classed as tyrosine-kinase inhibitors in the United States. These price increases are not restricted to just anticancer drugs; the cost of third-line HIV/AIDS treatments are now at least fourteen times higher than those negotiated for first-line therapies at the turn of the century (MSF 2014). In what follows, I track how it has become possible for Big Pharma to unilaterally dictate drug prices, as it frees itself from the constraints both of state control and global free market competition. I focus on cancer drugs as an exemplary case of runaway pharmaceutical pricing, brought about by deregulation and through the strategic blockage of global competition from countries such as India. I then track how Indian legal and regulatory actors struggle to re-animate the language of global south sovereignty and healthcare rights developed around HIV/AIDS, in order to curtail the rising prices of anticancer drugs. Through three defining legal controversies, I outline the potential and possibility of legal challenges to Euro-American pharmaceutical from governments and drug manufacturers located outside the region. Finally, less optimistically, I show how shifting pharma geopolitics and emergent biotechnological developments imperil the future of these legal challenges. In the broadest terms, I describe an attrition of legal and regulatory challenges from India to the Euro-American pharmaceutical industry with regard to drug pricing and patent rights. In its place, I find that Euro-American pharma has begun to successfully define the grammar of global pharmaceutical rights.

Anticancer drugs join a new cast of dramatis personae that has drawn the curiosity of social scientists of science and medicine. Amongst other entities, this cast includes cloned animals, immortalized cell lines, biological tissue, and the human genome project (cf. Franklin and Lock 2003; Heath, et al. 2008; Rajan 2006; Waldby 2002). These social analysts track how varied forms of global capital harness such biological materials, discovering new ways to produce economic value from biological life, thereby challenging normative understandings both of what constitutes life and how forms of life are differentially valued. In what follows, I focus attention on anticancer drugs as a crucial and controversial new biological material harnessed to economic value. I am particularly interested in how the co-production of new anticancer drugs and the regulatory regimes that control them transform our understanding of what constitute legitimate and illegitimate molecules, as well as our notions of their quality, efficacy, and the lawful means of their production. At stake is our understanding not only of what kind of value biological materials produce, but also how much value they can politically and legally sustain on a global scale. ${ }^{2}$ 


\section{Methods}

Anthropologists in the 1980s took to re-evaluating the discipline's ability to comprehend the complex flow of global processes, paving the way for experiments with research methods and widening the domains of legitimate inquiry (Marcus and Fischer 1986). Anthropological examinations of global biotechnology have been particularly enlivened by this upheaval of methods and objects (Dumit 2012; Ong and Collier 2005; Petryna, et al. 2006; Rajan 2012). As Sunder Rajan suggests, following global processes of biotechnology requires not only an attentiveness to shifting geopolitical scales, but also to temporal uncertainties, as technologies and the regulations guiding them are constantly in formation (Sunder Rajan 2006). In this article, I follow a dizzying range of actors and processes across a wide expanse of time and space. These include reconfigurations of the Indian drug industry since Indian independence, changing world trade regimes, new strategies of US and European corporations, and an increasingly neoliberal Indian state. Inevitably, studying such disparate and dispersed objects required methodological experimentation, ranging from the experience-near to the experience-distant. From 20112012, I conducted ethnographic research with urban poor cancer patients in and around Delhi, at which time the unavailability of pharmaceuticals was one among many barriers to accessible care. During this period, several legal appeals about cancer drug patents arrived at the Indian Supreme Court for resolution. I broadened my ethnographic work to include attending such court proceedings, and interviewed key legal experts involved in these cases. Subsequently, from 2012-2014, I interviewed key pharmaceutical consultants in New York City who guide US pharmaceutical policy in South Asia. Given the fraught professional stakes of their work, most consultants spoke to me under conditions of anonymity.

A substantial part of my research for this article employed methods other than traditional ethnography. From 2009-2015, I tracked local and global analyses of ongoing regulatory battles, media coverage, corporate materials, court documents, and archives of regulatory documents across the US and India. To comprehend the changing macro-trends of the global pharmaceutical industry, I consolidated and analyzed a range of financial databases, including Bloomberg Finance, Emerging Markets Information Service, Thomson One, CEIC Global Database and OSIRIS. I found it vital to move between the experiential and the statistical, the 'lifeworld' and 'system' (Marcus 1998). While a reassuring sense of place is certainly at stake in such methodological redefinitions, the strategic use of statistical and historical methods brings into view geopolitical processes that powerfully frame the uneven distribution of resources in the present.

\section{BIG PHARMA VS. PUBLIC GOOD}

Soon after Indian independence in 1947, Indian legislators sought to overturn the colonialera Indian Patents Act, finding in it a bias in favor of British corporations and manufacturing. After a decade of debate, a committee headed by Justice Ayyangar published a report that set the agenda for post-independence patent law (Ayyangar 1959). In this report, Justice Ayyangar argued that patent laws were a careful balancing act, where intellectual property rights (vital as they may be for innovation) had to be balanced against the collective rights of the public. The recommendations of this commission abolished 
'product' patents in drug manufacturing, replacing them with 'process' patents. This was a crucial opening for domestic drug manufacturers. In their postcolonial infancy, lacking advanced research and development capability, domestic drug makers could not compete with existing global pharma as they patented new drugs. Now that patenting shifted to the process of manufacture and not the product, domestic drug makers could manufacture drugs already developed by multinational pharma. All they needed to do was to alter the process of production, and then claim patent over the new process. Along with shifting the domain of what was patentable, the report also strengthened compulsory licensing provisions within patent law. These provisions - as I will show - were designed to allow the postcolonial state to over-ride the patent rights of multinational pharma in the interest of national sovereignty. The effect of this report as it became legislation was striking. Before 1970, international corporations dominated the Indian pharmaceutical landscape and commanded exorbitantly high prices for the drugs they made available. After the new Indian Patents and Designs Act of 1970, domestic manufacturers rapidly took the market share, and by the 1990s, domestic companies accounted for over 70 percent of production. These companies not only fulfilled domestic pharmaceutical demands; they also became a cheap, global pharmacy for other developing countries (Lanjouw 1998). For example, by recent estimates, 80 percent of 170,000 HIV patients treated globally by Doctors without Borders receive Indian generic ARVS (MSF 2005).

However, in keeping with a new set of policies to liberalize the economy, in 1995 India became a member of the WTO. Part of its WTO commitment included a promise to enforce the treaty's Trade Related Aspects of Intellectual Property Rights (TRIPS) provisions. Through 1995-2005, legislative bills were passed that harmonized India's intellectual property with the global TRIPS regime. Crucial to these changes was a return to colonial-era product patents, even in the domain of essential food and drugs that the Ayyangar Report had sought to protect. Emboldened by these developments, the Swiss pharmaceutical giant Novartis began litigation in 1997 to test the strength of India's WTO commitments. At the time, about ten Indian drug manufacturers were selling generic copies of Novartis' Gleevec - a breakthrough treatment for chronic myelogenous leukemia. Since its patent in 1993, Gleevec had become Novartis' most profitable drug, almost twice as much as the corporation's next best selling product. As one of the first cancer therapies that target particular cells, Gleevec represented a paradigmatic advance from the blunt chemotherapeutic formulations that destroyed all rapidly dividing cells, cancerous or not. For this, Gleevec is perhaps the only pharmaceutical product to ever make it to the cover of Time Magazine. It is worth nothing that Brian Druker - the researcher behind the drug has never made any money from this discovery, since Novartis had already patented the pre-trial molecule. He declared his discomfort with Gleevec's price, particularly because Novartis benefitted from public funds through his work at a state university (Druker 2007).

By the beginning of the twentieth century, Indian manufacturers had grasped the potential market for Gleevec and were selling the drug at a fraction of the price within the country. In 2004, a generic version became available to Indian consumers for about US $\$ 4230$ a year, compared to Novartis' asking price of about US \$55,000. Since Gleevec was discovered in 1993, and WTO laws were applicable only to drugs patented after 1995, these generic manufacturers imagined themselves to be in the legal clear. However, Novartis initiated legislation in the Indian courts to see how far they could push the new regulatory system. The strategy that Novartis adopted - 'evergreening' - is well-known to 
intellectual property watchers (Greenslit 2002). Novartis argued that modifications made to the original molecule had changed the drug to such an extent that it now constituted an entirely new product, one that had been patented in Switzerland in 2001. In light of that second patent, Indian generic manufacturers were breaking WTO laws. Novartis was confident of its strategy since it had already succeeded in enforcing its Swiss patent in 40 other countries. Much to the corporation's surprise, the Indian Patent Office decided to go against the global grain. The Assistant Controller of Patents, V. Rengaswamy, argued that there was no clinical evidence of an increase of efficacy of the second drug over the first. Within the provisions of India's implementation of the WTO, this was sufficient grounds to deny a new patent claim. The corporation would unsuccessfully challenge the decision in both the Madras High Court in 2007 and the Indian Supreme Court in 2013. After the Supreme Court judgment, PhRMA (the lobby group that represents nearly every major drug company in the US) threatened to withdraw all investments in India (PhRMA 2013). Throughout this lengthy legal battle, commentators worldwide praised the Indian courts for upholding the rights of the global poor. The New York Times coverage was indicative: "Production of the generic drugs in India, the world's biggest provider of cheap medicines, was ensured on Monday in a ruling by the Indian Supreme Court" (Harris and Thomas 2013).

Novartis's litigation to overturn the Indian Patent Office ruling rested upon three major claims. First, Novartis contended that the criteria of 'efficacy' through which the Patent Office distinguished between old and new drugs was not part of the WTO agreement. Therefore, the denial of their patent amounted to India's contravention of the WTO. Second, the term efficacy was too vague and allowed the Controller General of Patents "uncontrolled discretion", thus leaving companies to the mercy of his "whims and fancies" and the "arbitrary exercise of his power" (Madras High Court 2007). Based on this argument, the litigation contained a third claim: that such conceptual vagueness in the law discriminated against the person of Novartis, violating its fundamental rights. Thus, Novartis represented itself as a vulnerable legal global entity, beleaguered by errant local administrators and unreliable domestic regulatory language.

In response, the first maneuver for the Madras Court was to argue that an appeal to fundamental rights imposed a constitutional obligation upon the Indian judiciary to provide quick relief to the petitioner. This constitutional obligation proved to be Novartis' undoing. The constitutional obligation of Indian law was not towards the corporation, the Court argued, but rather towards vulnerable Indian citizens. Further, legal and regulatory languages were not languages of precision, nor were their interpretive breadth signs of legislative failure. Rather, the postcolonial constitution demanded interpretive space so that the judiciary could orient its judgments towards 'the public good'. Finally, the court demonstrated, words like 'efficacy' did not have an ahistorical definition, but drew meaning from their use by experts in the pharmaceutical field. Novartis's claim that the denial of the corporation's patent was an arbitrary exercise of power could only be understood as condescension towards local scientific expertise.

For more on the Gleevec debate, I refer the reader to anthropologists Stefan Ecks' and Kaushik Sunder Rajan's excellent analyses of the controversy (Ecks 2008; Rajan 2011). Ecks persuasively demonstrates that while anti-corporate groups celebrated the case, they failed to recognize that Novartis's real aim was not to sell the drug in India, for 
too few in the region could afford the drug to constitute a profitable market. Rather, the real concern was to make sure that Indian generics stayed within India, did not leak into the primary Euro-American markets, and did not challenge their global pricing

strategies. ${ }^{3}$ Moreover, through the process of court case, Novartis was able to highlight its own philanthropic patient access program in India and mobilize a small group patients and families who lobbied on their behalf. Thus, while Novartis failed to evergreen Gleevec, it succeeded in showcasing its corporate social responsibility, sowing the seeds for a potential future market. While Ecks alerts us to the limits of thinking of the Gleevec judgment as an anti-corporate victory, Sunder Rajan (2011) cautions against celebrating a legal mechanism that speaks entirely on behalf of sufferers, reducing patients to numbers and to the bare fact of their life or death. And in any case, he insightfully points out, "regardless of whether we are talking about free market competition through generic companies or monopoly through Novartis, most patients who need the drug cannot afford it" (Rajan 2011). In other words, this was not a battle between the free market and the state guarantee of healthcare. Rather, this was a battle between two versions of a marketized economy of health, neither of which met the needs of those who were suffering and who were at the center of this controversy. At the same time, crucially for what follows, Sunder Rajan explores significant gaps between these two different forms of the market. On the one side, Novartis stood for monopolistic practices undergirded by philanthropic gestures. On the other, the Patent Office upheld the principle of market competition, resisting monopolies in order to curtail the price of drugs. The victory of the latter over the former depended on interpretive practices that were guided by a constitutional obligation to define the state-citizen relationship above and apart from the consumer-corporation and philanthropist-recipient dyads. Another way to describe the difference between the two markets would be simply to point to their effects. As prices for Gleevec continued to rise in the US, generic Gleevec in India fell to even smaller fractions of Euro-American prices.

\section{ESCALATION}

In March 2012, the Indian Patent Controller at the time, P.H.Kurien, revisited the Ayyangar Report to issue the first compulsory drug license in Indian history. In his order, Kurien described compulsory licenses as an "involuntary contract between a willing buyer and an unwilling seller, imposed and enforced by the state" (2012). His order unilaterally forced German pharma giant Bayer (the unwilling seller) to allow a domestic drug maker, Natco Pharmaceuticals (the license applicant), to copy and sell its highly profitable liver and kidney cancer drug - Nexavar - within the bounds of the Indian market. If the Gleevec judgment had blocked the extension of an older oncology drug patent, the Nexavar order promised a more radical possibility: the voiding of exclusive patent rights for a drug well within its legal patent lifespan. This was not the first time that the Euro-American pharmaceutical industry had confronted this powerful tool of sovereign assertion. At the height of the HIV/AIDS controversy, South Africa, India and Brazil had formed a coalition to combat pressure from Euro-American governments to block the sale of generic therapies between countries in the global south. ${ }^{4}$ The global south coalition insisted that interpretations of the WTO-TRIPS agreement 
should supplant existing commitments to public health access: "We agree that the TRIPS Agreement does not and should not prevent Members from taking measures to protect public health. Accordingly, while reiterating our commitment to the TRIPS Agreement, we affirm that the Agreement can and should be interpreted and implemented in a manner supportive of WTO Members' right to protect public health and, in particular, to promote access to medicines for all" (World Trade Organization 2001). Based on this interpretive guidance, the coalition sought to strengthen compulsory licensing provisions to allow for the manufacture and export of essential life-saving drugs, especially in times of public health crises. In response, representatives of the US moved to limit the definition of public health crises to outbreaks of communicable diseases. Protracted negotiations over the last decade have failed to resolve this issue, and the demarcation of the terms 'crisis', 'epidemic,' and 'emergency' remain controversial. In fact, it reappears as a focal point in the controversy over the Trans-Pacific Partnership trade agreement (MSF 2016). In just a few paragraphs, P.H.Kurien had entered a decades long international battle and declared cancer to be legitimately constitutive of a public health crisis.

To receive a compulsory license for Nexavar under the Indian Patents Act, Natco Pharma had to meet one of three possible conditions: first, Nexavar had to be shown to be not available to the 'public' in the quantities that were required; second, it was not affordable to the average consumer; and third, Bayer had no intention of treating India as a viable market. Natco mobilized World Health Organization data to claim that about 16,000 patients in India required Nexavar on an annual basis. Bayer had failed to meet its domestic obligations by choosing to import less than a fraction of this requirement. Natco also successfully demonstrated that the monthly cost of Nexavar was 36 times the average monthly salary of an Indian government employee. As with Novartis' litigation concerning Gleevec, Bayer's response to these accusations turned upon the invalidity of local jurisprudence. Bayer argued that compulsory licenses were inimical to the spirit of the WTO, and that such legislative maneuvers were both ambiguously framed and unconstitutional. More specifically, Bayer's lawyers first attacked the vagueness of the terms 'reasonable', 'affordable' and 'public' in Natco's plea and Kurien's ruling. For instance, Bayer postulated that the term public was not monolithic: it included the rich, the middle and the poor. It then argued that the vague and imprecise definition of the public in Indian law to signify the poor over other sections of society demonstrated the inadequacy of Indian law. It then declared that such inadequate regulatory language victimized and discriminated against the person of Bayer. The Indian Patent Officer who had granted the patent on the grounds of 'reasonable' pricing had ignored what was reasonable for the corporation. Again mirroring Novartis, Bayer declared that it was willing to set a special philanthropic price for those in India that could not afford the drug. This price would come close to matching the generic cost, but only after patients demonstrated financial need to the extent of the corporation's liking.

Kurien's response to Bayer was dismissive. In the face of the unaffordability of the drug to nearly every patient in India, he stated that he did not need to employ lengthy reasoning to demonstrate that Bayer had violated the rights of the Indian public. He distinguished between the vulnerability of the poor and the vulnerability of Bayer as a corporation. Echoing the Madras High Court judgment, Kurien appealed to vulnerable Indian citizens as the primary 'public' to which Indian institutions were constitutionally obliged. Going further, Kurien dismissed Bayer's claim that its philanthropic practice of 
giving away drugs without charge freed the corporation from the responsibility of selling the drug in the market. Kurien argued that beyond philanthropy, working patents in a postcolonial context meant an attempt to disseminate technology from the global north to the south. Bayer could have fulfilled this requirement by manufacturing the drug in India, or voluntarily licensing Indian companies. It had failed to commit to either practice. The effect of Kurien's order on Nexavar prices in India was stunning. If a year of Nexavar therapy in the US costs approximately US\$180,000 per person per year, the price for generic Nexavar now (2016) in India is around US\$1,300 (under one percent of the US price).

While the international media did not pick up the far-reaching implications of this compulsory license, it raised strong concerns within the US government and the international pharmaceutical lobby. The Office of the United States Trade Representative - a crucial advisory body to the President - put India on a priority watch list for countries with inadequate intellectual property protection. This same threat of raised tariffs and withdrawn investments was made to the Mandela government when it took legislative action to secure access to generic HIV/AIDS therapies in the 1990s. Since 2013, India has re-appeared on the Priority Watch List of the Special 301 Report in 2014 and 2015. Both reports cite the Nexavar compulsory license as of the greatest concern. Indian trade policies were also put under a special review in 2014, a shaming tactic that the US government deployed against South Africa in 1999 and Brazil in 2007. The US pharmaceutical lobby publically condemned the legal proceedings in India, revealing the grounds of its concern. Take, for example, the intellectual property counsel for Pfizer, Roy Waldron, and his testimony before the House of Representatives in March 2013:

These decisions threaten to establish a dangerous precedent for other countries seeking to promote their own protectionist industrial policies. [...] If we are to avoid permanent harm to our ability to innovate new life saving and enhancing inventions, it is essential that we take all necessary measures to avoid a contagion effect [my emphasis] (Roy 2013).

My own interviews with a senior consultant for several US pharmaceutical companies echoed Waldron's public concern. This consultant admitted that most American pharmaceutical companies did not consider India to be a profitable consumer market; the high cost of oncology products place such drugs beyond the reach of nearly all Indian patients. The real concern for global pharma was the possibility of Indian judicial resistance setting a 'contagious' global precedent, as other governments in the global south could look within the flexibilities of their own WTO frameworks to protect and promote generic industries. Responding to pressure from the pharmaceutical lobby, 170 members of the US Congress signed a letter to President Obama, alerting him to the dangers of the Nexavar judgment in India. The letter raised the specter of outsourcing, arguing that this would hurt employment within the pharmaceutical industry in India: "The chilling effect in global R\&D investment as a result of India's intellectual property 
policies could have a direct impact on jobs and investment in the U.S. "(Paulsen 2013). This language seems directly lifted from the corporate lobby's Pfizer testimony: "The chilling effect on global R\&D investment, both in the US and in India, as a result of India's IP policies could have a significant negative impact on jobs and investments in the United States" (Roy 2013)

\section{QUALITY AND INEQUALITY}

With hindsight, the pharmaceutical lobby's fear of a contagion of generic anticancer drugs seems ill-founded. Since 2014, no other domestic drug maker has followed the example of Natco Pharma in seeking further compulsory licenses to produce anticancer formulations. In what follows, I turn to a new Big Pharma strategy that entangles molecular chemistry and global flows of capital to venture an explanation for this unexpected reluctance by Indian drug manufacturers to remain in the business of low-cost drugs.

In keeping with a shift towards its open-market economic policies, the Indian government deregulated the national pharmaceutical sector in 2002. This rolled back three key protective provisions put in place by the Ayyangar Report in 1970. First, the Ayyangar Report had strictly limited foreign investment in the Indian pharmaceutical sector. Deregulation meant that foreign investors could now buy out Indian firms with little or no governmental oversight. Second, the government lifted state price controls over many drugs that had been deemed too essential to be left to market control. Finally, it lifted obligations of technology transfer upon foreign investors, further easing their entry into the region. My statistical work with documents at the Department of Industrial Policy and Promotion and the Reserve Bank of India tracks the meteoric rise of foreign investments in the Indian pharmaceutical industry. Much of this investment originated from the host countries of Big Pharma - the United States, Western Europe, and Japan. From 1991-1999, non-Indian investment was \$246 million, averaging about \$31 million a year (Rajeswari and Akilandeswari 2015). In contrast, as shown in Figure 4, foreign investment from 2000-2015 was over $\$ 13$ billion dollars. In the last five years, foreign investments in Indian pharma have routinely crossed the $\$ 1$ billion mark every year. Figure 5 shows how the large majority of such investments originate from Europe, Japan and the United States - home to the world's largest pharmaceutical corporations.

At the same time, several multinational corporations have taken a more direct route into the country, merging with and acquiring Indian companies at extremely lucrative valuations. In November 2008, Daiichi Sankyo of Japan bought Ranbaxy Lab, one of India's oldest and most successful generic manufacturers, for US\$4.6 billion. While the industry leader in the pre-WTO period, Ranbaxy had been struggling to maintain its profitability in the post WTO-TRIPS regime. In 2015, Sun Pharma (India) and Ranbaxy-Daiichi Sankyo merged to form the largest pharmaceutical manufacturer in India, and the fifth largest in the world. Other notable acquisitions include the US-based Abbot Lab purchase of Indian Piramal healthcare for US\$3.2 billion in 2010. Novartis was not far behind. In March 2015, it traded its over-the-counter drugs and vaccines 
businesses for GlaxoSmithKline's oncology portfolio, both in India and worldwide. Bayer too ventured into the region, with a takeover of a Merck subsidiary - Fulford India. In turn, in May 2015, Natco Pharma decided to raise its foreign investment ceiling to 49 percent, calling for global capital to contribute $\$ 70$ million through shares and securities.

Publically frustrated by the encroachment of a global oligopoly within the domestic industry, the Indian Health Ministry decided to take unilateral action in 2013. An association of health activists had been lobbying the Indian government for a compulsory license on the break-through breast cancer drug, Herceptin. After Gleevec, Herceptin (generic name: Trastuzumab, patent held by Roche) has been another major landmark in the development of anticancer drugs. Its key ingredient is a monoclonal antibody that interferes with the HER-2 receptor; administration significantly reduces the risk of post-surgery recurrence for early-stage breast cancer patients with this receptor. Along with Gleevec, it is one of the highest selling cancer drugs in the world. In January 2013, the Indian Health Ministry announced the initiation of a process to issue compulsory licenses not only for Herceptin, but also for Ixempra (Ixabepilone) and Sprycel (Dasatinib). Ixabepilone is a new line chemotherapeutic formulation for breast cancer, while Dasatinib is an improvement upon Gleevec as a targeted therapy for chronic mylegenous leukemia. The American pharmaceutical giant Bristol-MyersSquibb holds both patents. Since no pharmaceutical corporation had approached the Indian Patent Office for a license to manufacture any of these drugs, the Health Ministry had invoked another provision placed within Indian Patent Law to enable it to take unilateral action and force a license of its own volition. This provision - Section 92 of the Indian Patents Act - gave the Indian state overwhelming sovereign power, allowing it to issue a compulsory license to any invention it found necessary to the public interest. Unsurprisingly, this move attracted WTO scrutiny as well as criticism within the Indian government and industrial lobbies that feared US trade reprisals. The Department of Industrial Policy and Promotion stalled the Health Ministry's proposal, producing a bureaucratic impasse.

However, in a curious turn of events in mid-2013, Roche decided to let its patent on Herceptin lapse without waiting for the Indian government to resolve its position. While this sudden change of heart confused many intellectual property watchers, I suggest that the molecular structure of the drug offers a probable explanation of Roche's about-face. The drugs that I have discussed in this article are part of a new cohort of targeted therapies for cancer. These drugs target cancers at a finer scale than older chemotherapeutic agents that bluntly attacked all rapidly dividing cells in the body cancerous or otherwise. Rather than killing tumor cells after the fact (cytotoxic agents), these new drugs draw upon advances in genetics and proteomics to interfere with the mechanism of cell reproduction at the molecular level, blocking tumor cell proliferation. Within this new world of targeted therapies, Herceptin occupies even more hallowed ground than Gleevec, Sprycel and Nexavar. Gleevec, Sprycel and Nexavar are all small molecule therapies that inhibit the growth-signaling pathway of cancer cells specifically, and are part of an older paradigm of pharmaceutical molecules: organic compounds synthesized through classic biochemical reactions. Herceptin - unlike other targeted therapies - is a large molecule drug made through recombinant DNA technologies across mice and humans. It interferes with highly specific growth receptors on the cell 
membrane and activates the immune system to differentiate between cancerous and noncancerous cells. The crucial point is that Herceptin is part of a new class of large molecule drugs called biologics or biopharmaceuticals, that are at the frontier of precision medicine because they are made up of active, chimeric human and animal biological material. They exhibit high molecular complexity and are much more sensitive to changes in the manufacturing process than classic small molecule drugs. Since no two cell lines are the same, and since generic manufacturers do not have access to the original manufacturers cell line banks, they cannot produce exactly the same product as the drug they intend to copy. Further, the process of optimization of the naturally occurring proteins is highly complex, involving further engineering via substitution of amino acids to make the now artificial protein superior to the already sophisticated living combination. In sum, unlike the traditional process of small molecule targeted therapies, biologics are notoriously difficult to copy. If classical small molecule products revealed nearly all about how they came to be manufactured, biologics are living organisms, unstable and shifty, unable to disaggregate to stable and universally available constituent parts. Thus, biologic copies - called biosimilars - have the potential to render transitions in patent regime moot. They require their own testing and approval process; the European Union established its own pathway in 2005, while the US put in place the Biologics Price Competition and Innovation Act within the text of the Affordable Care Act in 2010. As a testament to establishing a viable biosimilars, it took five years for the FDA to approve the first biosimilars product in the US in 2015. With the European Union's five-year head start, about 19 biosimilars are currently approved for the market. Significantly, biosimilars shift the controversy away from the politics of intellectual property, to the politics of globally tiered scientific capability. Roche was gambling on this uneven layering of expertise, on the difficulty of producing the drug and having its quality approved. Just a few months earlier, Ranbaxy had pleaded guilty in a US court to the FDA charge of not producing drugs under current good manufacturing practices established by the agency. Much was made of this controversy in the US media, as the question of drug quality quickly overwhelmed reportage about the Indian generic industry. As Bharadwaj and Glasner (2009) have shown in their work on stem cell research in India, global standards of 'good manufacturing practices' are loaded with ethical and political meaning, and are often part of metropolitan strategies to discredit scientific practitioners elsewhere.

Keenly aware of this shifting and somewhat hostile nature of the world pharmaceutical landscape, the Indian Department of Biotechnology drafted the first set of guidelines for the approval of biosimilars in India in 2012. In the meantime, Biocon pharmaceuticals - arguably India's largest biotech firm - had already been selling the first Indian oncology monoclonal antibody - BIOMAb. It had obtained a license for the drug in 2006 by partnering with the Cuban Center for Molecular Immunology that had developed the original molecule. Since that time, several other Indian companies have started partnering with European and American laboratories and investing heavily in biologic research and development. Thus, when Roche let its patent lapse, five Indian manufacturers took on Roche's challenge: Biocon, Dr. Reddy's Lab, Intas, Reliance Life Sciences, and BDR Pharma. Biocon (in association with the American firm Mylan pharmaceuticals, a US-based generic manufacturer) was the first past the research and development mark for Herceptin. However, as many intellectual property experts had 
predicted, Roche launched a successful lawsuit against Biocon and Mylan, claiming that their biosimilar was not comparable to their original drug. In April 2016, the Delhi High Court ruled in favor of Roche, barring Biocon and Mylan from marketing their drug as comparable to Roche's Herceptin. In May 2016, Roche sued Hetero Drugs to prevent the Indian drug manufacturer from marketing a biosimilar for Avastin - a monoclonal antibody used to treat colorectal, lung, breast, renal and brain cancers.

In consonance with Bharadwaj and Glasner's description of stem-cell science, Cori Hayden's work (2007) on the generic industry in Mexico demonstrates that unlike high-profile compulsory licensing battles elsewhere, the battle between multinational and domestic pharma unfolds over the biochemical quality of already legal copies. With regard to generics, Hayden opens up the notion of quality as an open-ended, controversial site of ethnographic investigation. She demonstrates how making finer and finer distinctions about generic quality has become a key global pharma strategy for discrediting the production of generics. The innovation of biosimilars in the biosciences gives this technical-political tool an entirely new power and meaning. If Indian biotech firms are able to successfully develop generic biosimilars, they will face a new set of challenges on this reformulated question of quality.

Now transnational collaboration, partnerships, and buyouts begin to look increasingly sensible. In this unevenly tiered world of biotech expertise, the boundaries between generic Indian manufacturers and multinational pharma - Little Pharma and Big Pharma - are beginning to blur to the point of indistinction. On the one hand, global corporations have begun to buy out old generic manufacturers in India. On the other, Indian manufacturers have come to increasingly depend on global collaborations to be able to compete in the contemporary drug marketplace. Undeterred, Indian firms now seek to play on Big Pharma's turf, themselves beginning to acquire R\&D facilities in the global north in order to bolster their manufacturing and development capabilities. Drawing upon my research across several company financial databases, in Figure 6 I demonstrate a dramatic increase in market concentration within the Indian pharma industry. I have calculated this increase through the Herfindahl-Hirschman Index, a widely accepted measure of market concentration developed first by the philosopher and political economist Albert O. Hirschman. The range for the HHI is 0-10,000, where higher numbers indicate increasing market competition. The trend lines are divided into the biologics-capable and non-biologics oriented segments within the industry. While both segments show a dramatic increase in concentration by the end of 2014, the biologics market shows an increasing trend towards concentration and consolidation. Mergers and deals that increase market concentration by more than 100 usually attract regulatory antitrust concerns. Here, the period between the 2012-13 and 2013-14 financial years saw increase $>100$ in both the biologic and non-biologic segments.

Thus, recent trends seem to predict an increasingly monopolistic and decreasingly competitive Indian pharma market, one infused with foreign venture and pharma capital. And if we are to learn from the global north example, large monopolies are able to circumvent both state regulations and market competition, and thus set prices exactly as they please.

What then about much older drugs that are scheduled to lose their patent status past the point of the 20-year scope WTO protections? This is perhaps Big Pharma's most 
pressing concern, as the industry moves closer towards what intellectual property watchers calls the 'patent cliff'. The term refers to the coincidental expiry of a series of worldwide patents by 2019 that are estimated to hurt Big Pharma's revenues by about $\$ 65$ billion dollars (GlobalData 2014). While optimists searching for worldwide access might hope that for at least such older drugs, generic pricing will be as low as they have historically been, there are reasons for serious misgivings. As both Big and Little Pharma move towards conjoined oligopolic forms, the potential for price fixing and noncompetitive agreements escalate. Without the threat of global competition and a global generic market that will increasingly include Europe and America, there remains little incentive for Indian manufacturers to sell cheap drugs on a mass scale. In other words, there are few stumbling blocks to the consolidation of financial arrangements that will capitalize on these new biological materials, and the potential they encode.

\section{FUTURE HORIZONS}

In examining modes of precision in science and law, Bruno Latour (2010) has argued that in both their form and practice, legal judgments tend to a closure of possibility, and to produce the boundaries of law as incontrovertible and seamless. Further, he suggests that scientific work commits itself to an opposite movement, away from equilibrium and closure, and towards instability and an openness of meaning. For my analysis of judicial work in relation to science in India, Latour's typology seems problematic. Legal and scientific practices neither disaggregate themselves into such distinct modes, nor do they remain distant from determinations of political economy. Rather, global pharmaceutical companies construct a hyper-technical language of both law and science in order to undermine the role of the Indian State and its legal actors (and by analogy, many other specific national/ global entanglements). Their singular grammar configures molecular life, the global market and legal language such that corporations emerge as the true upholders of international law and the sole gatekeepers of legitimate pharmacogenomics. Those that challenge them appear archaic, contractually illegitimate, and producers of dubious biochemical quality. In contrast, judicial and regulatory work in India has sought to contest the power of corporations to unilaterally define the interpretive practice of international law and its attendant scientific vocabulary. In so doing, it has sought to empower agentive state actors to test the correctness of legal and scientific interpretation through the framework of a constitutional obligation towards sovereign citizens.

In contrast to Latour's formulation, Sheila Jasanoff (2011) offers the term bioconstitutionalism to analyze precisely such movements of legal and scientific coproduction, where in the ever-shifting movements between law and science, the questions of rights as well as the nature of state-citizen relations are transformed in contingent ways. Yet, as Kaushik Sunder Rajan (2012) points out, the mutual investments of life sciences and capital can be described in ways that are attentive to contingency, without reifying the contingent as itself the ultimate form of explanation. I want to develop Sunder Rajan's sense that the co-production of life sciences and capital are often overdetermined by calculations of political economy. ${ }^{5}$ Here, I have traced the co-production of life and law, and more specifically, drugs and the rights that accrue to them. Yet, in the unfolding of this co-production, the processes of global capital are able to 
successfully define the terms through which we understand the nature of drugs, the legitimate means of their production, and the modes of their ownership. The historical relation between legal rights and pharmacogenomics is certainly uneven and varied enough to produce several kinds of contingent outcomes. We have seen one such possibility, in the particular mode of legal reasoning that privileges a notion of the public good and the right to health over the rights of corporations to globally define and price anticancer drugs. Yet, hegemonic forms of over-determination appear with a sort of inevitability, as the Indian state increasingly inhibits its obligations to its citizens, constrained by its obligations to global pharmaceutical capital. The success of global pharmaceutical capital then has been to set up a determining epistemological frame: international law, intellectual property rights, our understanding of the pharmaceutical molecule, the legitimate means of its production, and the illegitimacy of its variant forms. Within the confines of these terms, challenges to global capital can only remain intermittent and particularist, at best confined to exceptional legal interventions that are themselves too few and far in between. Thus, while the battle over anticancer drugs in the Indian courts still offer some friction, the corrosive forces of global pharmaceutical capital and its attendant regulatory regimes seem increasingly capable of ironing out such resistance.

The lessons gained here from peeling off the layers of recent history from a 'global south' perspective are instructive across many national boundaries where pharmaceutical markets are now highly expansive. As Ann Stoler and John and Jean Comaroff warn us, stable antinomies of metropole and colony begin to wear down very quickly as we track the fluid movements of capital across the spaces they have produced (Comaroff and Comaroff 2011; Stoler 2006). The south has long been the petri dish for capital-driven experiments that reformulated legal and political boundaries. In India, we see a new iteration of this historical process, as corporations - both old and new experiment with new forms of governance and capital to fashion an increasingly oligopolic global drug marketplace.

\section{ACKNOWLEDGMENTS}

I thank Emily Martin, Tejaswini Ganti, Rayna Rapp, Faye Ginsburg, Helena Hansen, Sienna Craig, Cori Hayden and the science studies working group at NYU, all of who provided invaluable commentary on early versions of this paper. Many of the findings that appear here were presented as a Grand Rounds lecture at Dartmouth-Hitchcock Medical Center, The Annual Conference on South Asia at the University of Wisconsin, the Science Studies in South Asia Conference at the University of Hawai'i, the American Anthropological Association annual meeting in Chicago, and the University of Chicago Center in Paris. 


\section{FUNDING}

My research for this project was supported by residency fellowships from the Mellon Foundation at the Leslie Center for the Humanities at Dartmouth College, and from the Humanities Initiative at NYU. I also received funding from the National Science Foundation and the Wenner-Gren Foundation.

\section{REFERENCES}

Ayyangar, N. R.

1959 Report on the revision of the patent laws. Delhi, India: Government of India.

Bharadwaj, A. and P. Glasner

2009 Local Cells, Global Science: The Rise of Embryonic Stem Cell Research in India. London and New York: Routledge.

Biehl, J.

2004 The activist state: Global pharmaceuticals, AIDS, and citizenship in Brazil. Social Text 22(3):105-132.

Biehl, J. and A. Petryna

2011 Bodies of rights and therapeutic markets. Social Research: An International Quarterly 78(2):359-386.

Bond, P.

1999 Globalization, pharmaceutical pricing, and South African health policy. International Journal of Health Services 29(4):765-792.

Cassedy, C.

2014 Transcript of bayer CEO Marjin Dekkers quote at the December 32013 Financial Times Event. http://keionline.org/node/1924.

Comaroff, J. and J. L. Comaroff

2011 Theory from the South: Or, How Euro-America is Evolving Toward Africa. Boulder, CO: Paradigm Publishers.

Druker, B.

2007 Don't abuse patents. Livemint, August 15.

Dumit, J.

2012 Drugs For Life: How Pharmaceutical Companies Define Our Health. Durham, NC: Duke University Press.

Ecks, S. 
2008 Global pharmaceutical markets and corporate citizenship: The case of Novartis' anti-cancer drug Glivec. BioSocieties 3(2):165-181.

Farmer, P., et al.

2010 Expansion of cancer care and control in countries of low and middle income: A call to action. Lancet 376(9747):1186-93.

Franklin, S. and M. Lock

2003 Remaking Life and Death: Toward an Anthropology of the Biosciences. Santa Fe, NM and Oxford, UK: School of American Research Press.

GlobalData

2014 Global Pharmaceutical Market Benchmark Report. GlobalData.

Greenslit, N.

2002 Pharmaceutical branding: Identity, individuality, and illness. Molecular Interventions 2(6):342-345.

Harris, G. and K. Thomas

2013 Low-cost drugs in poor nations get a lift in Indian court. New York Times, April 1, 2013.

Hayden, C.

2007 A generic solution? Current Anthropology 48(4):475-495.

Heath, D., R. Rapp, and K. S. Taussig

2008 Genetic citizenship. In A Companion to the Anthropology of Politics. D. Nugent and J. Vincent, eds. Oxford, UK: Blackwell Publishing Ltd.

Jain, S. L.

2013 Malignant: How Cancer Becomes Us. Berkeley, CA: University of California Press.

Jasanoff, S.

2011 Reframing Rights: Bioconstitutionalism in the Genetic Age. Cambridge, MA: MIT Press.

Kurien, P. H.

2012 Decision on compulsory license application in respect of patent no.

215758. Department of Industrial Policy and Promotions, ed. Mumbai, India: DIPP.

Lanjouw, J. O.

1998 The Introduction of Pharmaceutical Product Patents in India: Heartless Exploitation of the Poor and Suffering? Cambridge, MA: National Bureau of Economic Research.

Latour, B. 
2010 The Making of Law: An Ethnography of the Conseil d'Etat. Malden, MA: Polity.

Livingston, J.

2012 Improvising Medicine: An African Oncology Ward in an Emerging Cancer Epidemic. Durham, NC: Duke University Press.

Madras High Court

2007 Novartis vs. Union of India. Chennai, India: Madras Law Reporter. Mahmud, N.

2014 Letter from Nina Mahmud to Philip Blake. Geneva, Switzerland: Knowledge Ecology International.

Marcus, G. E.

1998 Ethnography Through Thick and Thin. Princeton, NJ: Princeton University Press.

Marcus, G. E., and M. M. J. Fischer

1986 Anthropology as Cultural Critique: An Experimental Moment in the Human Sciences. Chicago, IL: University of Chicago Press.

MSF

2005 Will the lifeline of affordable medicines for poor countries be cut? consequences of medicines patenting in India. Geneva, Switzerland: Campaign for Access to Essential Medicines.

2014 Untangling the web of antiretroviral price reductions. Campaign for Access to Essential Medicines 16.

2016 Trading away health: The trans-pacific partnership agreement. MSF.

\section{Ong, A. and S. J. Collier}

2005 Global Assemblages : Technology, Politics, and Ethics as Anthropological Problems. Malden, MA: Blackwell Publishers Ltd.

Paulsen, E.

2013 Bipartisan letter pressing for action on India's intellectual property violations. Washington, D.C.: Congress of the United States.

Petryna, A., A. Lakoff, and A. Kleinman, eds.

2006 Global Pharmaceuticals: Ethics, Markets, Practices. Durham, NC: Duke University Press.

PhRMA

2013 PhRMA statement on Indian Supreme Court decision on Glivec. 
Rajan, K. S.

2006 Biocapital: The Constitution of Postgenomic Life. Durham, NC: Duke University Press.

2011 Property, rights, and the constitution of contemporary Indian biomedicine: Notes from the Gleevec case. Social Research: An International Quarterly 78(3):975-998.

2012 Lively Capital: Biotechnologies, Ethics, and Governance in Global Markets. Durham, NC: Duke University Press.

Rajeswari, G. R. and K. Akilandeswari

2015 Sector-Wise foreign direct investment inflows into India. Journal Of Business Management \& Social Sciences Research 4(1):73-77.

Roy, W.

2013 Written testimony of chief Intellectual Property Counsel, Pfizer. In United States House of Representatives Energy \& Commerce Committee Subcommittee on Commerce, Manufacturing and Trade. Washington, D.C.

Stoler, A. L.

2006 On Degrees of Imperial Sovereignty. Public Culture 18(1):125-146.

Waldby, C.

2002 Stem Cells, Tissue Cultures and the Production of Biovalue. Health 6(3):305-323.

World Trade Organization

2001 Declaration on the TRIPS Agreement and Public Health. WTO Ministerial Conference, Doha, Qatar. 


\section{Market Concentration of Indian Pharmaceutical Industry (2010-2014)}

\section{Market Segment}

Biologics

Nonbiologics

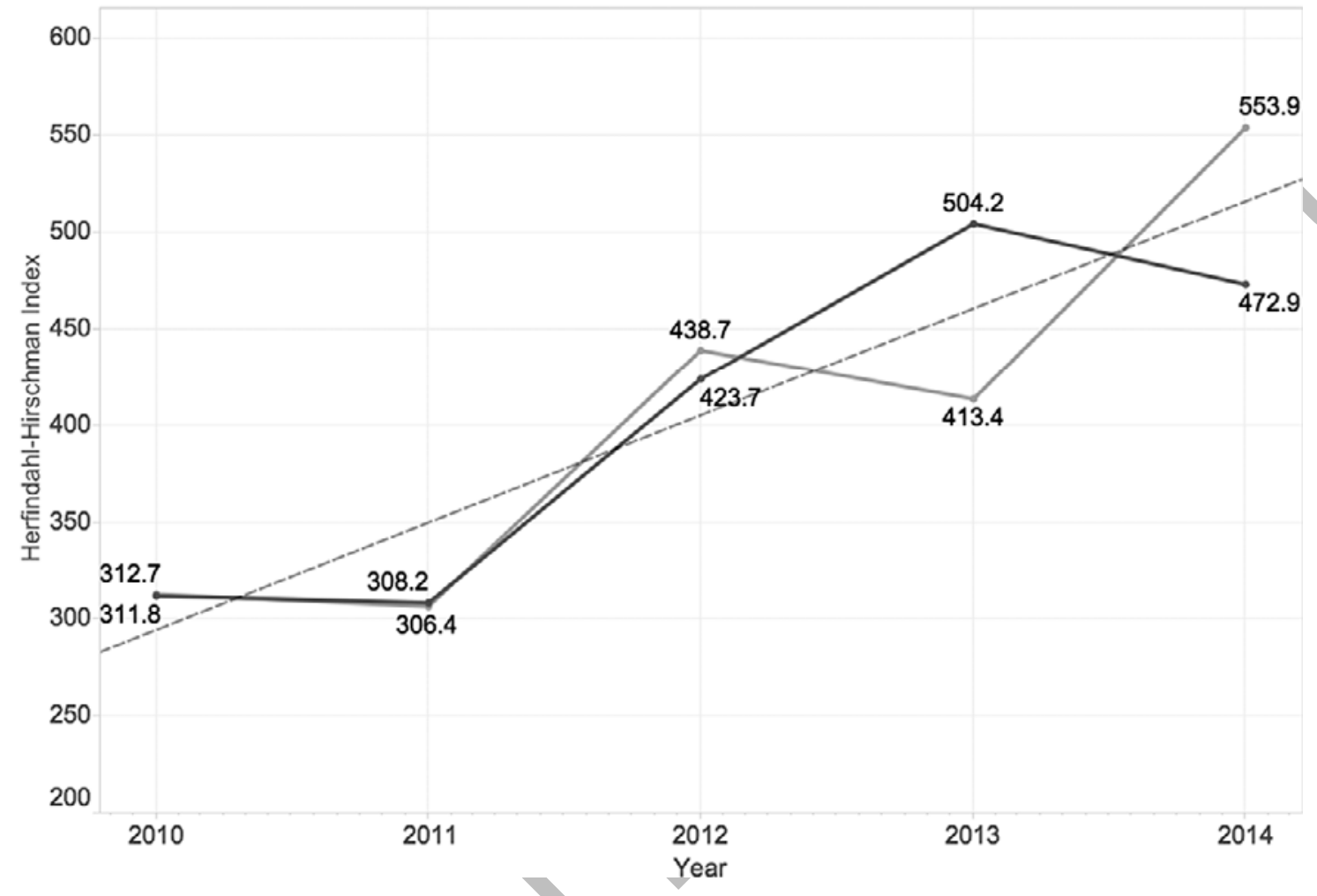


Tyrosine-Kinase Inhibitors Prices: 2006-2015

Generic Name (Brand Name)

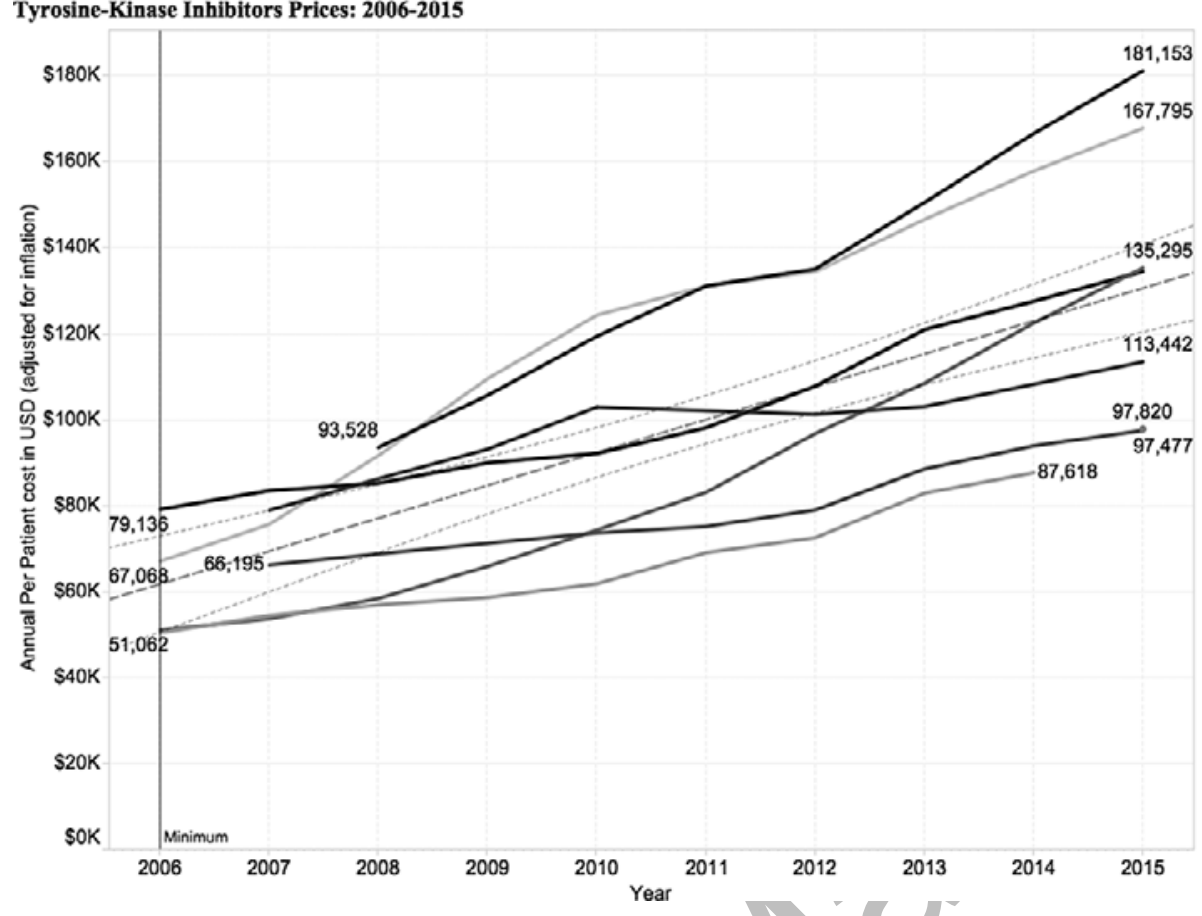

Gefitinib (Iressa)

Lapatinib (Tykerb)

Erlotinib (Tarceva)

Nilotinib (Tasigna)

Imatinib Mesylate (Gleevec)

Sunitib (Sutent)

Sorafenib (Nexavar)

Dastinib (Sprycel) 
Historical Price Trend of Imatinib Mesylate (Gleevec): 2004-2015

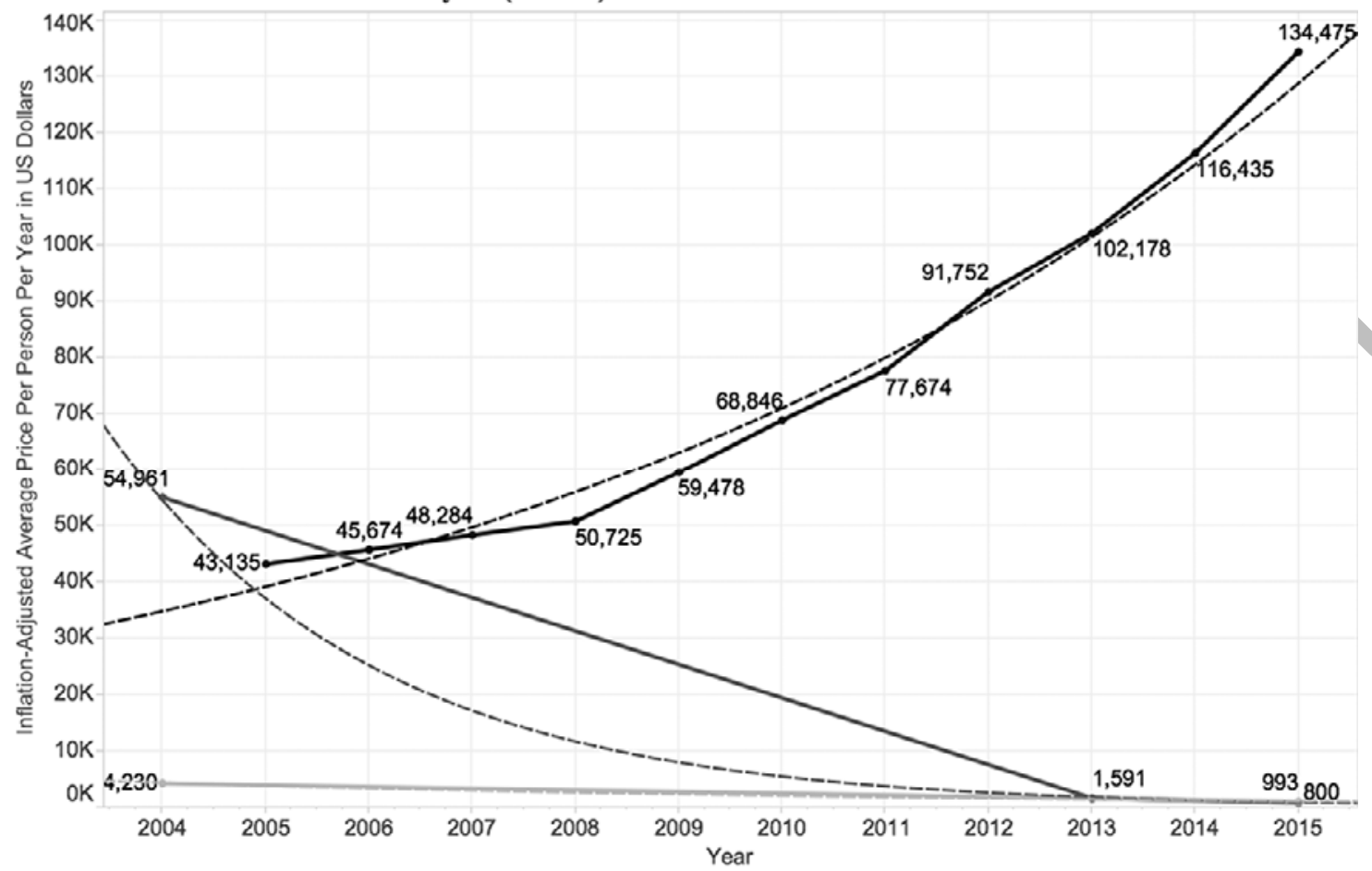

Generic Price in India

Novartis Price in India

Novartis Price in US 
Sorafenib (Nexavar) Historical Price Trend: 2012-2015

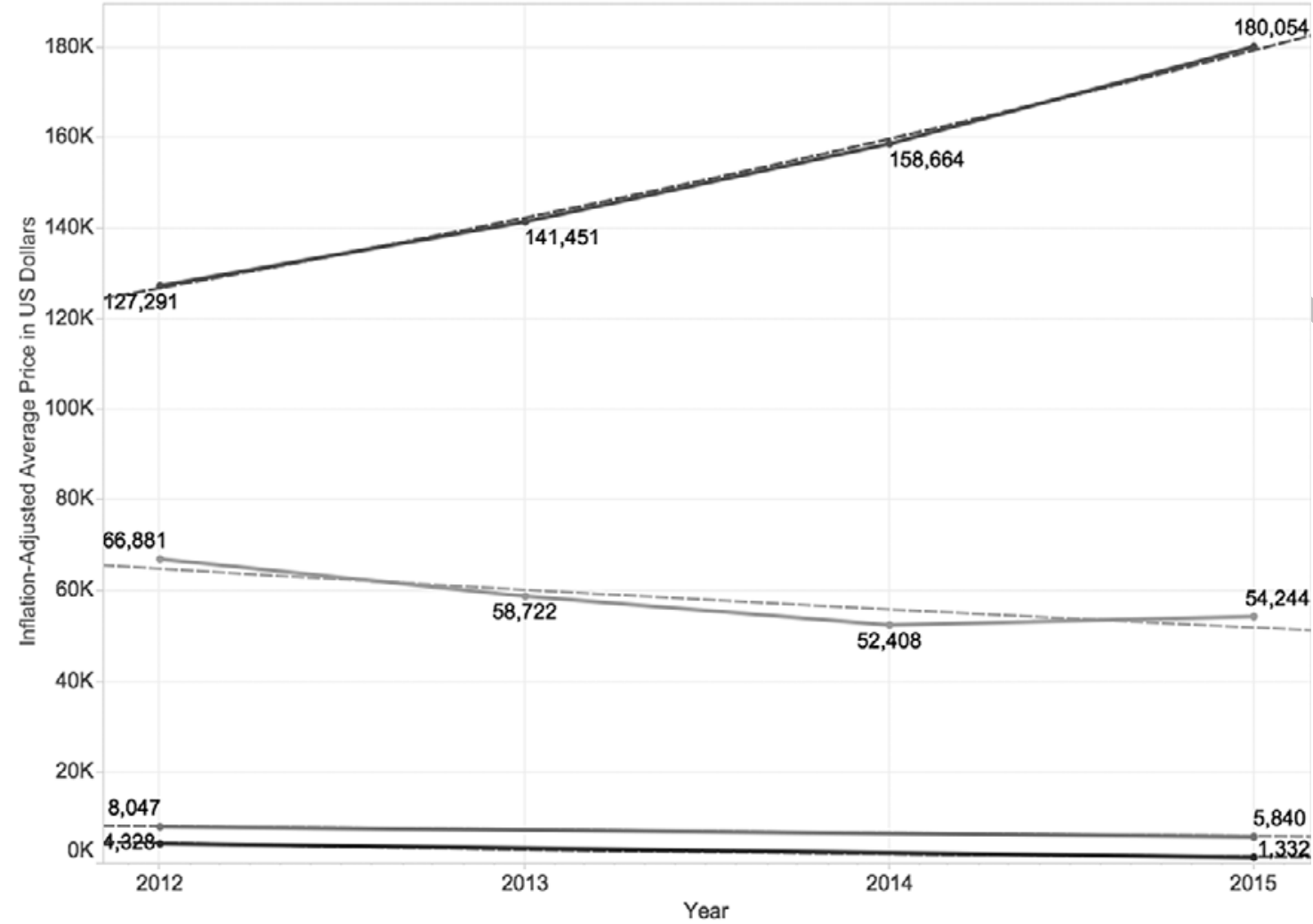

Bayer - United States

Bayer - India

Generic - India

Bayer - India Philanthropic Price 


\section{Foreign Dlrect Investment in the Indian Pharmaceutical Sector}

Annual Inward FDI in Indian Pharmaceutical Sector (2000-2015)

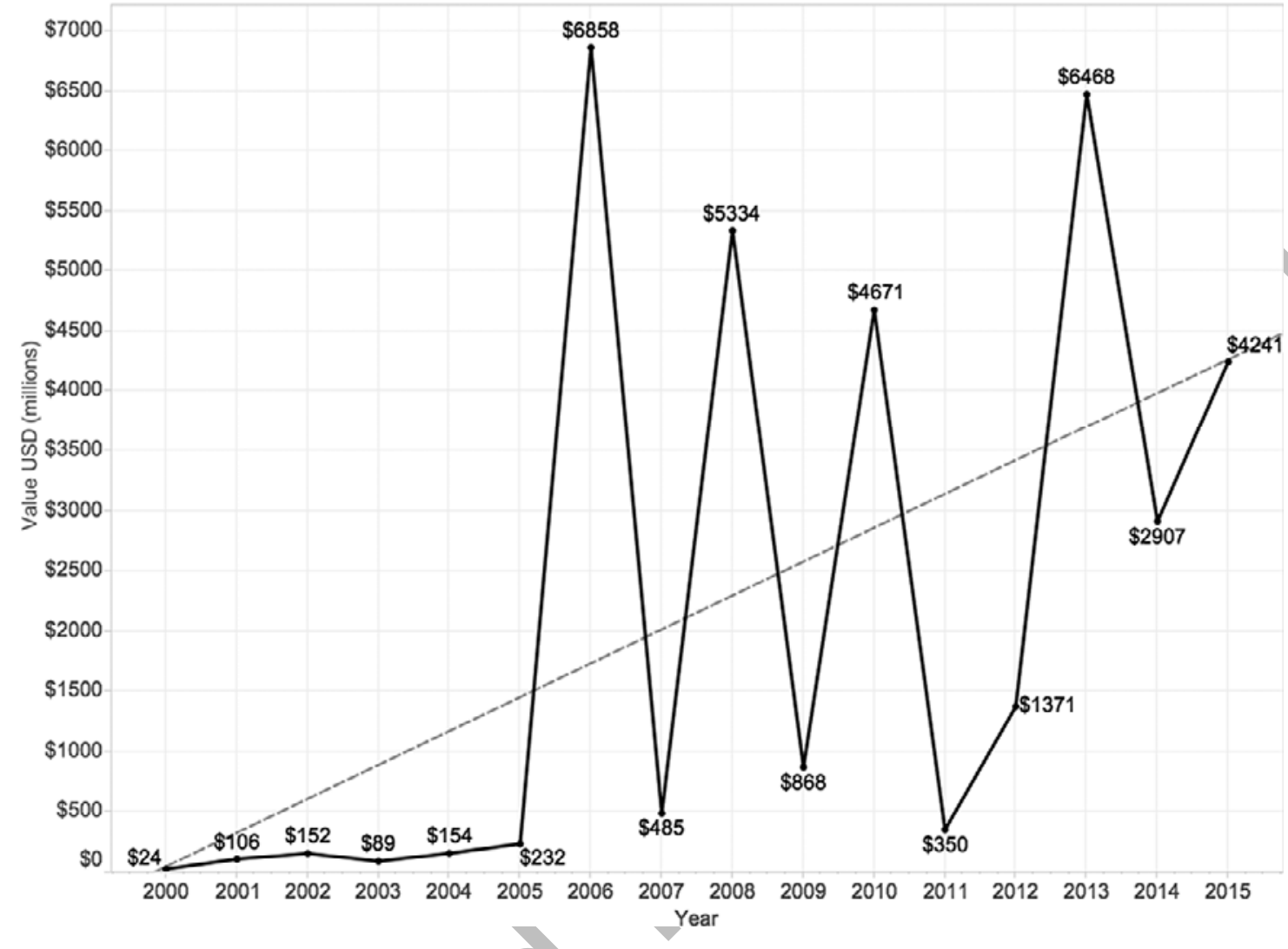


Geographical Distribution of FDI in Indian Pharmaceutical Sector (2000-2015)

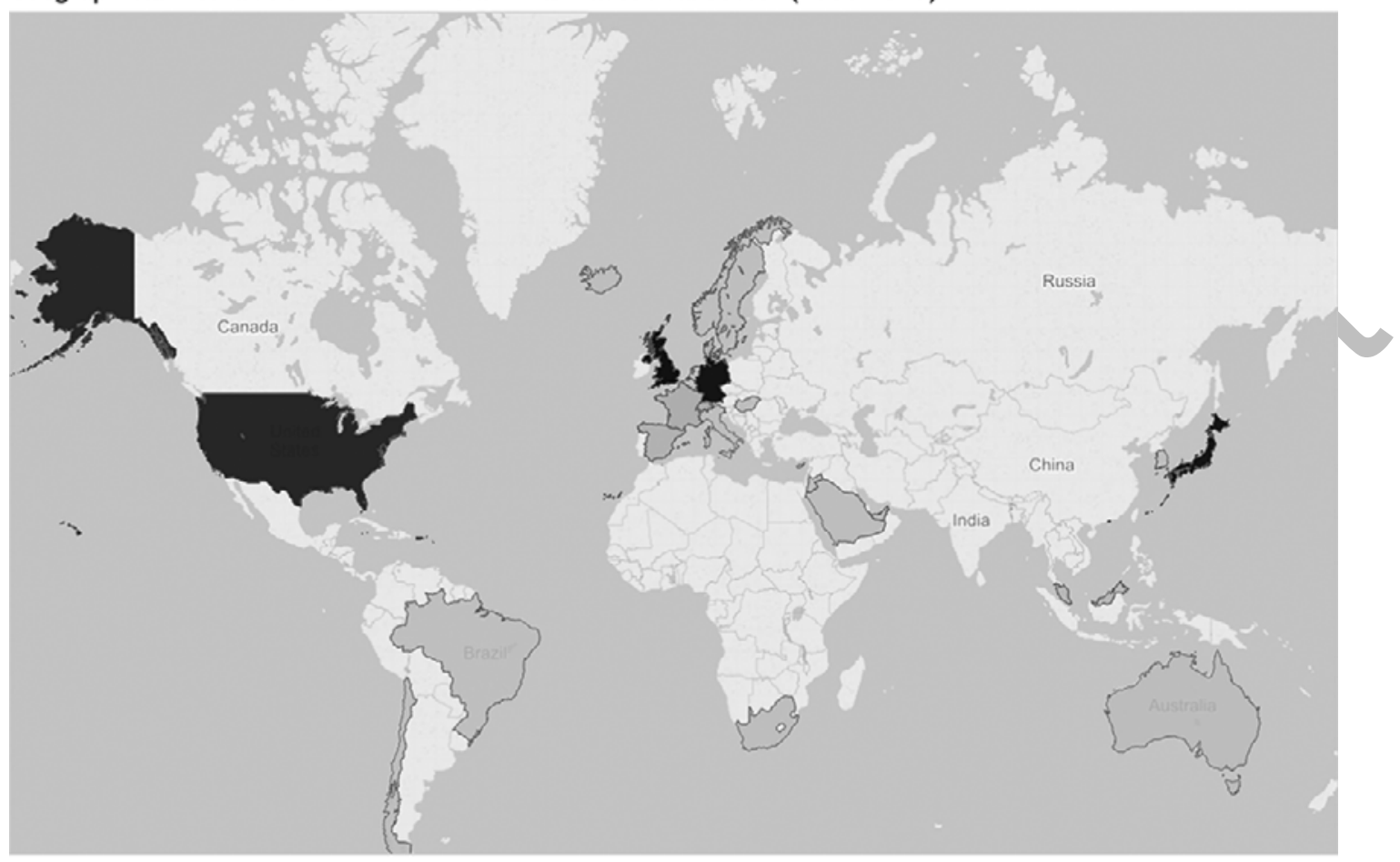

Total in USD (millions) 


\section{NOTES}

${ }^{1}$ In this article, the loosely defined term Big Pharma will refer to about 15 of the world's largest multinational pharmaceutical companies, each of whose annual revenues exceed US \$15 billion.

${ }^{2}$ In tracking Big Pharma's strategies and their contestation, I do not equate healthcare rights with the legal mandate to ensure drug access. In their work on the changing forms of public health in Brazil, anthropologists Biehl and Petryna Biehl, J., and

\section{A. Petryna}

2011 Bodies of rights and therapeutic markets. Social Research: An International Quarterly 78(2):359-386. describe how universal public health has increasingly been reframed as a matter of the legal right to access a global pharmaceutical market. In the face of failing public health infrastructures, increasing healthcare costs, and fragile medical collectivities, such a narrowing judicialized and pharmaceuticalized vision of healthcare rights distracts attention from basic health infrastructure and access.

${ }^{3}$ In 2013, India's largest drug manufacturer - Sun Pharma - filed litigation in New Jersey to try and employ reasoning similar to the India Patent Office to bring generic Gleevec to the United States in 2014. Novartis claimed that its patents over the drug were valid until 2019. After a year of negotiations, the two companies settled on February 1, 2016 as the release date for generic Gleevec in the US. 
${ }^{4}$ This coalition included the Africa Group, Barbados, Bolivia, Brazil, Dominican

Republic, Ecuador, Honduras, India, Indonesia, Jamaica, Pakistan, Paraguay, Philippines, Peru, Sri Lanka, Thailand and Venezuela.

${ }^{5}$ I am using the word over-determined here in the sense given to us by Kaushik Sunder Rajan in his introduction to Lively Capital. Situating Marx as an epistemologist (among other orientations), Sunder Rajan uses over-determination not to indicate economic determinism, but how configurations of political economy set the stage for not only value, but the epistemological frameworks through which we understand value. 